\title{
Investigation on the Current Situation of Seventh Grade Students in Yunnan Ethnic Areas Taking WD Minority Middle School in Yunnan, China as an Example
}

\author{
Xuemei Sun ${ }^{1, *}$ Ruixia $\mathrm{Xu}^{2}$
}

\author{
${ }^{1}$ Teacher Teaching Development Center, Qujing Normal University, Qujing, Yunnan 655011, China \\ ${ }^{2}$ The High School Attached to Yunnan Minzu University, Kunming, Yunnan 650031, China \\ *Corresponding author. Email: sunrose1970@126.com
}

\begin{abstract}
Through the questionnaire survey, the article investigates the status of seventh-grade students in ethnic areas in three dimensions of non-intelligence factors, learning adaptability, learning habits and methods. The survey shows that firstly, the status of students in the dimension of non-intellectual factors is that most students have a certain interest in mathematics learning, but the internal driving force of learning is not strong enough for knowledge. The attitude of learning is not optimistic, but learning self-confidence is good. Secondly, in terms of learning adaptability, students' understanding of teaching content and classroom listening, completion of homework after class, and self-monitoring ability of summary and reflection after learning failure are generally better. However, students are poor in independent thinking ability, reasonable arrangement of study plans and independent management of study time, and execution of learning tasks according to study plans. Most students have difficulty in learning because they have too many subjects to study, cannot reasonably arrange study time, and do not understand teachers' explanations well. This means that students still need to enhance their self-active learning consciousness. Thirdly, the current status of students' learning methods and habit factors are: students' habit of previewing before class and summing up after class is better. Students' classroom listening methods and question examination methods are also worth advocating, but the specific implementation strength needs to be improved. The habit of inquiring information after class is not well developed and needs to be improved. Therefore, in mathematics teaching, it is necessary to pay attention to training students to develop good mathematics learning habits, enhance students' self-management ability, stimulate students' motivation to learn, and enhance learning initiative and autonomy. It is also necessary to consolidate students' mathematics foundation, and pay attention to the guidance of students' mathematics learning methods at the same time.
\end{abstract}

\section{Keywords: mathematics learning, current situation survey, non-intelligent factors, learning adaptability}

\section{INTRODUCTION}

The Chinese province of Yunnan is home to 26 ethnic minorities, making it the province with the most ethnic minorities in the country. Chuxiong Yi Autonomous Prefecture is a Yi Autonomous Prefecture in Yunnan Province. The prefecture inhabits 26 ethnic groups including Yi, Miao, Lisu, Hani, Dai and Han, with a minority population of 837,600 , accounting for $32.62 \%$ of the total population. [1] This article takes seventh grade students from WD Minority Middle School in Chuxiong, Yunnan, China as the survey object, and investigates the mathematics learning status

*Project: Phased results of the 2019 teacher project of Yunnan Provincial Department of Education (Project No.: 2019J0614). of seventh grade students from three dimensions: nonintelligence factors, learning adaptability, learning methods and habits. The research has a certain positive role in promoting the quality of education and teaching in ethnic areas, narrowing the gap in mathematics education among regions, and promoting the improvement of the quality of mathematics education in ethnic areas and the balanced development of compulsory education.

\section{RESEARCH DESIGN}

\section{A. Research content and purpose}

By investigating the status of seventh grade students in Yunnan ethnic areas of China in the three dimensions 
of non-intelligence factors, learning adaptability and learning habits and methods, it is to understand the problems in the mathematics learning of seventh grade students in Yunnan ethnic areas of China, and put forward corresponding mathematics teaching suggestions to provide certain references and guidance for effectively improving the teaching and learning of mathematics in ethnic areas.

\section{B. Subject selection}

271 seventh grade students from WD Minority Middle School in Chuxiongzhou, Yunnan, China were selected as subjects, including students from 7 ethnic groups including Yi, Han, Lisu, Dai, Miao, Bai, Hani, among which $\mathrm{Yi}$ students accounted for $47.2 \%$, and other minority students accounted for $21.8 \%$, and Han students accounted for $30.3 \%$.

\section{Research methods and tools}

The research used a questionnaire survey. The survey tool "Mathematics Learning Questionnaire" was compiled with reference to relevant questionnaires by Li Jinfu and Huang Yijun [2], [3]. The questionnaire was tested and revised many times after soliciting expert approval and review by front-line teachers in the middle school. Finally, 24 questions were selected, 1 of which was multiple-choice, and the rest were singlechoice questions. The questionnaire involves three dimensions: non-intelligence factors, learning adaptability, and learning methods and habits.

\section{Reliability and validity of the questionnaire}

The survey sent 271 questionnaires and withdrawn 271 questionnaires. The reliability and validity of the recovered questionnaire were tested with SPSS20.0. The reliability coefficient of the $\alpha$ of the questionnaire was 0.975 after analysis. The factor analysis method was used to measure the validity structure, and the KMO values of the questionnaire were 0.970 , indicating that the test has good reliability and validity, thus ensuring the reliability of the research.

\section{SURVEY RESULTS AND ANALYSIS}

In this paper, Excel 2003 and education statistical software SPSS 20.0 are used to analyze and process the data. [4] The coding method of the survey results is: for the multiple choice questions, specific numeric coding options are used, A-1, B-2, C-3, D-4, E-5. The multiple choice questions are arranged from negative to positive, with hierarchical and sequential characteristics, and are assigned 1, 2, 3, and 4, respectively. For multiplechoice questions, a binary variable method is used to give each option a code, and each option is either selected or not selected. When the value is marked, 1 is used to indicate that the option is selected, and 0 indicates that the option is not selected.

\section{A. The dimension of non-intellectual factors}

The dimension of non-intelligence factors involves four aspects: mathematics learning motivation, mathematics learning interest, learning attitude, and learning confidence.

1) Learning motivation: Learning motivation is one of the important factors affecting mathematics learning, which directly affects the students' learning level and effect.

TABLE I. LEARNING MOTIVATION STATISTICS

\begin{tabular}{|c|c|c|c|c|}
\hline Learning motivation & Frequency & Percent & Valid Percent & Cumulative Percent \\
\hline Have to study because of further education & 60 & 22.1 & 22.1 & 22.1 \\
\hline Students' affirmation and enhancement of the sense of achievement & 33 & 12.2 & 12.2 & 34.3 \\
\hline Teachers' praise or parents' award & 29 & 10.7 & 10.7 & 45.0 \\
\hline Like math and willing to challenge & 149 & 55.0 & 55.0 & 100.0 \\
\hline
\end{tabular}

"Table I" shows that 55\% of students study mathematics out of their own interests and hobbies, while $22.9 \%$ students' mathematics learning is stimulated by external objective conditions, such as teacher praise, parental rewards, and classmates' affirmation; $22.1 \%$ of students are in a passive state; most students are not very purposeful about mathematics learning, and their motivation for mathematics learning is unclear, which brings great obstacles to the teaching and learning of mathematics.

2) Learning interest: It is shown as follows. It can be seen from "Table II": $65.7 \%$ of students have no habit of learning in extracurricular activities, and are keen on other recreational activities. Only $11.4 \%$ of students will summarize themselves, and $13.3 \%$ and $8.9 \%$ of students take time to review old classes and preview new classes. About classroom activities, $84.5 \%$ of students will actively cooperate with teachers and classmates, but $15.2 \%$ of students are not active in mathematics classroom activities. In terms of interest in mathematics learning, $40.6 \%$ of students are very interested in mathematics, $42.8 \%$ are not interested in mathematics, and $16.6 \%$ are not interested in mathematics learning. 
TABLE II. LEARNING INTEREST STATISTICS

\begin{tabular}{|c|c|c|c|c|c|}
\hline Learning interest & & Frequency & Percent & $\begin{array}{c}\text { Valid } \\
\text { Percent }\end{array}$ & $\begin{array}{c}\text { Cumulative } \\
\text { Percent }\end{array}$ \\
\hline \multirow{4}{*}{$\begin{array}{l}\text { Extracurricular } \\
\text { learning interest }\end{array}$} & Entertainment & 178 & 65.7 & 66.2 & 66.2 \\
\hline & Review the old lessons & 36 & 13.3 & 13.4 & 79.6 \\
\hline & Conclude and summarize & 31 & 11.4 & 11.5 & 91.1 \\
\hline & preview the new curriculum & 24 & 8.9 & 8.9 & 100.0 \\
\hline \multirow{4}{*}{$\begin{array}{c}\text { Classroom activities } \\
\text { learning interest }\end{array}$} & Passive participation, coping & 11 & 4.1 & 4.1 & 4.1 \\
\hline & Not really like & 30 & 11.1 & 11.1 & 15.2 \\
\hline & $\begin{array}{l}\text { Listen to the teacher's arrangement, the harvest is } \\
\text { not small }\end{array}$ & 131 & 48.3 & 48.5 & 63.7 \\
\hline & Actively participate and cooperate with classmates & 98 & 36.2 & 36.3 & 100.0 \\
\hline \multirow{4}{*}{$\begin{array}{l}\text { Mathematics learning } \\
\text { interest }\end{array}$} & No interest & 4 & 1.5 & 1.5 & 1.5 \\
\hline & Have been interested in & 41 & 15.1 & 15.1 & 16.6 \\
\hline & Little interest in & 116 & 42.8 & 42.8 & 59.4 \\
\hline & Full of interest & 110 & 40.6 & 40.6 & 100.0 \\
\hline
\end{tabular}

3) Learning attitude: The learning attitude mainly includes the students' learning of mathematics and their attitude towards the examination of mathematics.

TABLE III. LEARNING ATTITUDE STATISTICS

\begin{tabular}{|c|c|c|c|c|c|}
\hline Learning attitude & & Frequency & Percent & Valid Percent & $\begin{array}{c}\text { Cumulative } \\
\text { Percent }\end{array}$ \\
\hline \multirow{4}{*}{$\begin{array}{l}\text { Mathematics learning } \\
\text { attitude }\end{array}$} & It is boring and unwilling to learn & 6 & 2.2 & 2.2 & 2.2 \\
\hline & Hot and cold, unstable & 93 & 34.3 & 34.3 & 36.5 \\
\hline & Practice and be willing to learn & 129 & 47.6 & 47.6 & 84.1 \\
\hline & Very love to learn, willing to learn & 43 & 15.9 & 15.9 & 100.0 \\
\hline \multirow{4}{*}{ Test attitude } & $\begin{array}{l}\text { Comfort themselve as if nothing had } \\
\text { happened }\end{array}$ & 21 & 7.7 & 7.7 & 7.7 \\
\hline & Be in a panic before the exam & 66 & 24.4 & 24.4 & 32.1 \\
\hline & Take it seriously and be meticulous & 159 & 58.7 & 58.7 & 90.8 \\
\hline & Be confident & 25 & 9.2 & 9.2 & 100.0 \\
\hline
\end{tabular}

It can be seen from "Table III" that $63.5 \%$ of the students are willing to learn mathematics, but $36.5 \%$ of the students have an unreasonable learning attitude, lack of enthusiasm, and their personal learning consciousness is not strong. $32.1 \%$ of learners have insufficient self-confidence in exams and they dare not agree with their learning ability. However, $67.9 \%$ of the learners have good psychological qualities and will take an objective and positive view of the test results. Even if a certain degree of errors occur during the test, they can actively summarize and reflect, learn lessons and improve learning leaks and shortcomings.

4) Learning confidence: It is shown as follows. According to the statistical results in "Table IV", 62\% of students have great confidence in learning mathematics well, and about $5.2 \%$ of students have low confidence in learning.

TABLE IV. LEARNING CONFIDENCE STATISTICS

\begin{tabular}{|l|l|l|l|l|}
\hline \multicolumn{1}{|c|}{ Learning confidence } & \multicolumn{1}{|c|}{ Frequency } & \multicolumn{1}{c|}{ Percent } & Valid Percent & Cumulative Percent \\
\hline No confidence & 3 & 1.1 & 1.1 & 1.1 \\
\hline A little confidence but no progress & 11 & 4.1 & 4.1 & 5.2 \\
\hline Have confidence but do not know the effect & 88 & 32.5 & 32.6 & 37.8 \\
\hline Believe that he will master & 168 & 62.0 & 62.2 & 100.0 \\
\hline
\end{tabular}

\section{B. Dimension of learning adaptability}

Learning adaptability is mainly investigated and analyzed from the aspects of learning plan and execution, learning adaptability, self-monitoring, learning results, learning difficulties and so on.

1) Learning plan: It can be seen from "Table V" that only $27.3 \%$ of the students have plans and 
complete on time, $43.9 \%$ of the students have plans but the actions are discounted, $17.7 \%$ of the students have plans but basically do not complete, and $11.1 \%$ of the students have no plans.

TABLE V. LEARNING PLAN STATISTICS

\begin{tabular}{|l|l|l|l|l|}
\hline & Frequency & \multicolumn{1}{|c|}{ Percent } & Valid Percent & Cumulative Percent \\
\hline No plan & 30 & 11.1 & 11.1 & 11.1 \\
\hline Have a plan, but basically don't finish it & 48 & 17.7 & 17.7 & 28.8 \\
\hline Have a plan, but action is compromised & 119 & 43.9 & 43.9 & 72.7 \\
\hline Have a plan, and it can be completed & 74 & 27.3 & 27.3 & 100.0 \\
\hline
\end{tabular}

2) Learning adaptability: Learning adaptability mainly includes students' adaptability to teachers' teaching situation and teaching content.

TABLE VI. LEARNING ADAPTABILITY STATISTICS

\begin{tabular}{|c|c|c|c|c|c|}
\hline Adaptability & & Frequency & Percent & $\begin{array}{c}\text { Valid } \\
\text { Percent }\end{array}$ & $\begin{array}{c}\text { Cumulative } \\
\text { Percent }\end{array}$ \\
\hline \multirow{4}{*}{$\begin{array}{c}\text { Adaptability } \\
\text { on teachers' } \\
\text { teaching } \\
\text { condition }\end{array}$} & $\begin{array}{l}\text { In order to complete the teaching schedule, the teaching has no plan and the } \\
\text { time is not scientific }\end{array}$ & 3 & 1.1 & 1.1 & 1.1 \\
\hline & It focuses on textbook knowledge, but ignores students' actual learning ability & 23 & 8.5 & 8.5 & 9.6 \\
\hline & $\begin{array}{l}\text { The teaching content and teaching method are both considered, but the } \\
\text { teaching arrangement is not strict }\end{array}$ & 30 & 11.1 & 11.1 & 20.7 \\
\hline & $\begin{array}{l}\text { Combine the actual situation, design carefully, choose the appropriate } \\
\text { teaching method }\end{array}$ & 215 & 79.3 & 79.3 & 100.0 \\
\hline \multirow{4}{*}{$\begin{array}{c}\text { Adaptability of } \\
\text { teaching } \\
\text { content }\end{array}$} & Teaching content is not novel, deviating from reality, boring and tasteless & 25 & 9.2 & 9.3 & 9.3 \\
\hline & $\begin{array}{l}\text { With the teaching material knowledge primarily, often contact with other } \\
\text { disciplines }\end{array}$ & 15 & 5.5 & 5.6 & 14.8 \\
\hline & Furtherly deepen and improve on the basis of textbook knowledge & 101 & 37.3 & 37.4 & 52.2 \\
\hline & Create a learning situation to combine knowledge with practice & 129 & 47.6 & 47.8 & 100.0 \\
\hline
\end{tabular}

TABLE VII. SELF-MONITORING STATISTICS

\begin{tabular}{|c|c|c|c|c|c|}
\hline Self-monitoring & & Frequency & Percent & $\begin{array}{c}\text { Valid } \\
\text { Percent }\end{array}$ & $\begin{array}{l}\text { Cumulative } \\
\text { Percent }\end{array}$ \\
\hline \multirow{4}{*}{ Time of listening } & Not listen at all & 3 & 1.1 & 1.1 & 1.1 \\
\hline & Listen for a minute and do the other things when understand & 31 & 11.4 & 11.4 & 12.5 \\
\hline & Listen most of the time and occasionally do something else & 146 & 53.9 & 53.9 & 66.4 \\
\hline & Listen to the whole lesson carefully & 91 & 33.6 & 33.6 & 100.0 \\
\hline \multirow{4}{*}{$\begin{array}{c}\text { Operation } \\
\text { completion }\end{array}$} & Give up when don't know how to do & 13 & 4.8 & 4.8 & 4.8 \\
\hline & Discuss with classmates & 115 & 42.4 & 42.4 & 47.2 \\
\hline & Refer to the math materials & 43 & 15.9 & 15.9 & 63.1 \\
\hline & Independently accomplish & 100 & 36.9 & 36.9 & 100.0 \\
\hline \multirow{4}{*}{$\begin{array}{c}\text { Coping with } \\
\text { problem-solving } \\
\text { obstacles }\end{array}$} & Leave a blank for the question that doesn't know & 16 & 5.9 & 5.9 & 5.9 \\
\hline & Ask teachers or classmates if can't solve in a few minutes & 69 & 25.5 & 25.5 & 31.4 \\
\hline & $\begin{array}{l}\text { Look for links between known conditions and required } \\
\text { problems }\end{array}$ & 89 & 32.8 & 32.8 & 64.2 \\
\hline & Do it in a different way if the original one doesn't work & 97 & 35.8 & 35.8 & 100.0 \\
\hline \multirow{4}{*}{$\begin{array}{l}\text { Master of problem- } \\
\text { solving method }\end{array}$} & Often use own methods & 5 & 1.8 & 1.8 & 1.8 \\
\hline & Can apply, but not fully understood & 41 & 15.1 & 15.1 & 17.0 \\
\hline & Can master, but the application is not flexible & 167 & 61.6 & 61.6 & 78.6 \\
\hline & Can master and apply flexibly & 58 & 21.4 & 21.4 & 100.0 \\
\hline
\end{tabular}

It can be seen from "Table VI" that $79.3 \%$ of the students can adapt to the teacher's teaching method and affirm the teacher's teaching situation; $84.9 \%$ of the students believe that the teacher's teaching content and the reality are combined and they can understand the teaching content. It means that the students have a higher average value in understanding the teacher's teaching plan and teaching content, indicating that the students' learning adaptability is stronger.
3) Self-monitoring: Good self-monitoring ability in mathematics learning mainly refers to the ability of conscious self-regulation and self-monitoring and good reflection. The statistical results in "Table VII" show that the students' self-monitoring ability is good, and most students can effectively use classroom learning time, reasonably respond to classroom learning obstacles, and improve classroom learning efficiency. $52.8 \%$ of students can complete their assignments 
consciously, independently, or with the help of classmates or teachers. $78.6 \%$ of students can actively look for coping methods when coping with problemsolving obstacles, and change the way of thinking to find problem-solving methods. In terms of classroom problem-solving methods, $61.6 \%$ of the students can master the classroom content, but the application is not flexible, and $21.4 \%$ of the students can master and apply flexibly.

4) Learning outcome: The learning outcome is the ability of students to self-reflect, summarize and organize the knowledge they have learned, and be able to use the knowledge flexibly to solve practical problems.

TABLE VIII. LEARNING OUTCOME STATISTICS

\begin{tabular}{|c|c|c|c|c|c|}
\hline Learning outcome & & Frequency & Percent & Valid Percent & Cumulative Percent \\
\hline \multirow{4}{*}{$\begin{array}{l}\text { Attribution of } \\
\text { learning failure }\end{array}$} & Own failure & 3 & 1.1 & 1.1 & 1.1 \\
\hline & $\begin{array}{l}\text { Did not understand in the class, poor } \\
\text { memory and other reasons }\end{array}$ & 65 & 24.0 & 24.1 & 25.2 \\
\hline & No guidance from teachers or parents & 1 & 4 & 4 & 25.6 \\
\hline & $\begin{array}{l}\text { Their usual efforts are not enough, to take } \\
\text { this as a lesson }\end{array}$ & 201 & 74.2 & 74.4 & 100.0 \\
\hline \multirow{4}{*}{$\begin{array}{l}\text { Master level after } \\
\quad \text { class }\end{array}$} & Don't even understand the book & 8 & 3.0 & 3.0 & 3.0 \\
\hline & $\begin{array}{l}\text { Know the knowledge from textbook but } \\
\text { don't know how to use }\end{array}$ & 32 & 11.8 & 11.8 & 14.8 \\
\hline & $\begin{array}{l}\text { Understand the formula in the book, but } \\
\text { can't apply flexibly }\end{array}$ & 159 & 58.7 & 58.7 & 73.4 \\
\hline & Achieve mastery & 72 & 26.6 & 26.6 & 100.0 \\
\hline
\end{tabular}

It can be obtained from the statistical results in "Table VIII" that $74.2 \%$ of the students can reasonably attribute attribution when they encounter setbacks in mathematics, actively sum up the subjective reasons for learning failures and learn lessons, and adjust improper learning methods in time. $58.7 \%$ of the students can master the classroom knowledge but the application is not flexible, and $26.6 \%$ of the students can integrate the knowledge in the classroom.

5) Learning disability: This mainly analyzes students' problems in math learning and their strategies to deal with them.

TABLE IX. LEARNING DISABILITY STATISTICS

\begin{tabular}{|l|l|l|l|l|}
\hline & Frequency & Percent & \multicolumn{1}{|c|}{ Valid Percent } & Cumulative Percent \\
\hline Often do not understand some mathematical concepts 165 & 60.9 & 60.9 & 62.0 \\
\hline $\begin{array}{l}\text { Often can not memorize the mathematical formula } \\
\text { Can't read some graphics, and can't draw some } \\
\text { graphics }\end{array}$ & 12.5 & 12.5 & 74.5 \\
\hline Don't know some mathematical symbols & 9.2 & 9.2 & 83.8 \\
\hline
\end{tabular}

TABLE $X . \quad$ STATISTICS OF COPING STRATEGIES WHEN FACING WITH UNKNOWN QUESTIONS

\begin{tabular}{|l|l|l|l|l|}
\hline & \multicolumn{1}{|c|}{ Frequency } & \multicolumn{1}{c|}{ Percent } & \multicolumn{1}{c|}{ Valid Percent } & \multicolumn{1}{c|}{ Cumulative Percent } \\
\hline Don't think he can solve it, so give it up & 12 & 4.4 & 4.4 & 4.4 \\
\hline Copy other people's answers & 18 & 6.6 & 6.7 & 11.1 \\
\hline Ask a classmate, parent or teacher & 179 & 66.1 & 66.3 & 77.4 \\
\hline Ruminate on his own & 61 & 22.5 & 22.6 & 100.0 \\
\hline
\end{tabular}

"Table IX" and "Table X" show that the main difficulties for students in learning are: $60.9 \%$ of students often do not understand mathematical concepts, and $16.2 \%$ of students are unfamiliar with some mathematical symbols. The main difficulty for $62 \%$ of students is to study many subjects and the pressure to learn. The main difficulty for $52 \%$ of students is not understanding the teacher's explanation. The methods adopted by students to cope with learning difficulties are: $66.1 \%$ of students who encounter problems will ask for advice from classmates, parents or teachers, and $22.5 \%$ of students choose to think independently.

\section{Dimension of learning methods and habits}

This is mainly to investigate students' mathematics learning methods and learning habits. 
TABLE XI. METHODS AND HABIT STATISTICS

\begin{tabular}{|c|c|c|c|c|c|}
\hline \begin{tabular}{c|}
$\begin{array}{c}\text { Methods and } \\
\text { habit }\end{array}$ \\
\end{tabular} & & Frequency & Percent & $\begin{array}{c}\text { Valid } \\
\text { Percent }\end{array}$ & \begin{tabular}{|c|} 
Cumulative \\
Percent
\end{tabular} \\
\hline \multirow{4}{*}{$\begin{array}{c}\text { Preview } \\
\text { condition } \\
\text { before class }\end{array}$} & Never preview & 24 & 8.9 & 8.9 & 8.9 \\
\hline & Flip through the math book & 74 & 27.3 & 27.3 & 36.2 \\
\hline & Look at the math formulas in the textbook and recite while reading & 99 & 36.5 & 36.5 & 72.7 \\
\hline & Mark important places in math books & 74 & 27.3 & 27.3 & 100.0 \\
\hline \multirow{4}{*}{$\begin{array}{l}\text { Summary level } \\
\text { after class }\end{array}$} & There is usually no summary & 29 & 10.7 & 10.7 & 10.7 \\
\hline & The teacher always does the summary & 27 & 10.0 & 10.0 & 20.7 \\
\hline & Teachers often make summaries, and occasionally let students make summaries & 59 & 21.8 & 21.8 & 42.4 \\
\hline & Often let students sum up first, then teachers add & 156 & 57.6 & 57.6 & 100.0 \\
\hline \multirow{4}{*}{$\begin{array}{l}\text { Listening } \\
\text { methods }\end{array}$} & $\begin{array}{l}\text { Listen to the teacher teach mathematical formulas, theorems and rules and } \\
\text { recite them }\end{array}$ & 28 & 10.3 & 10.4 & 10.7 \\
\hline & Listen to the teacher teach math examples, exercises and recite them & 19 & 7.0 & 7.0 & 17.8 \\
\hline & $\begin{array}{l}\text { Listen to the teacher talk about mathematical formulas, theorems and laws and } \\
\text { think about them }\end{array}$ & 114 & 42.1 & 42.2 & 60.0 \\
\hline & Listen to the teacher teach math examples, exercises and think alone & 108 & 39.9 & 40.0 & 100.0 \\
\hline \multirow{4}{*}{$\begin{array}{l}\text { Question } \\
\text { analysis } \\
\text { methods }\end{array}$} & Every number must be useful & 22 & 8.1 & 8.1 & 8.1 \\
\hline & Sometimes the known facts in the questions are useless & 24 & 8.9 & 8.9 & 17.0 \\
\hline & The correct answer must be worked out by the numbers in the question & 14 & 5.2 & 5.2 & 22.2 \\
\hline & There must be a connection between what is known and what is required & 210 & 77.5 & 77.8 & 100.0 \\
\hline \multirow{4}{*}{$\begin{array}{l}\text { Information } \\
\text { query }\end{array}$} & Never look up & 63 & 23.2 & 23.2 & 23.2 \\
\hline & Look up after the teacher assigns & 28 & 10.3 & 10.3 & 33.6 \\
\hline & Look up when needed & 164 & 60.5 & 60.5 & 94.1 \\
\hline & Often look up & 16 & 5.9 & 5.9 & 100.0 \\
\hline
\end{tabular}

It can be obtained from the statistical results in "Table XI" that the habits of students to preview before class are generally better, but they still need to be improved. $27.3 \%$ of the students will carefully preview, draw doubt points and key points in the textbook. Classroom summary is good, but most cases are summarized by the teacher, and $10.7 \%$ of them have no summary at all. $83 \%$ of the students can think independently during the course of listening to the lectures, and most of the students can find solutions to the problems according to the known and unknown conditions given by the questions. There is less access to extracurricular information, and only $5.9 \%$ of the students can independently access it.

\section{Conclusion}

Through the investigation and analysis, the following conclusions are obtained:

The current status of students in the dimension of non-intellectual factors is: most students have some interest in mathematics learning, but the internal driving force of learning is not strong enough for knowledge, and learning attitude is not optimistic, but learning selfconfidence is better.

In terms of learning adaptability, students' overall understanding of teaching content and classroom listening, completion of homework after class, and summary and reflective self-monitoring ability after learning failure are generally better. However, students' are poor in the independent thinking ability, reasonable arrangement of study plans and independent management of study time, and execution of learning tasks according to study plans. Most students have difficulty in learning because they have too many subjects to study, cannot reasonably arrange study time, and do not understand teachers' explanations well. This means that students still need to enhance their selfactive learning consciousness.

In terms of learning methods and learning habits, the current status of students' learning methods and habit factors is: good habits such as pre-class preparation and after-class summary, but they still need to be cultivated and improved; students' classroom listening methods and question examination methods are also worth promoting. However, the specific implementation efforts need to be strengthened; the habit of inquiring after-school information is not well developed and needs to be improved. [5]

According to the survey conclusion of the seventh grade students' mathematics learning in Yunnan ethnic areas of China, it is necessary to pay attention to training students to develop good mathematics learning habits. It is also necessary to enhance students' selfmanagement ability, motivate students' learning motivation, and enhance learning initiative and autonomy. At the same time, it is should consolidate students' mathematics foundation, and also pay attention to the guidance of students' mathematics learning methods. 


\section{References}

[1] Fang Tie, Distribution, Origin and Characteristics of Crossborder Ethnic Groups in Yunnan Province [J]. Journal of Guangxi University For Nationalites: Social Science Edition, 2007, 29 (5). (in Chinese)

[2] Li Jinfu, Ding Yunhong, Investigation and Research on the Concept of Solving Mathematical Problems of Primary School Students in Yi Nationality [J]. Ethnic Education Study, 2012, (2). (in Chinese)

[3] Huang Yijun, Chen Bifen, Status Quo of Mathematics Learning and Strategies in Ethnic Minorities [J]. Journal of Southwest China Normal University (Natural Science), 2011, 36(4). (in Chinese)

[4] Wu Minglong, Questionnaire Statistical Analysis Practice: SPSS Operation and Application [M]. Chongqing: Chongqing University Press, 2010: 63-75. (in Chinese)

[5] Xu Ruixia, A Survey of Yi's Seventh Grade Students' Mathematics Learning Situation from the Perspective of Characterization: A Case Study of WD National Middle School in Yunnan Province [D]. Kunming: Yunnan Normal University, 2017, 6. (in Chinese)

[6] Lu Xiushuang. Cross-cultural Research of Mathematical Ability of Uygur and Han Middle School Students in Different Regions [J]. Journal of Research on Education for Ethnic Minorities, 2004,15 (5). (in Chinese)

[7] Zhu Weizong, Yang Chenglun, et al. A Cross Culture Studying Report on Mathematical Ability of Junior Middle School Students of Yunnan Minority People [J]. Journal of Mathematics Education, 2000, 9 (2). (in Chinese) 